\title{
Semiotika dalam Lagu Che.r.ry dan Summer Song Karya Yui Yoshioka
}

\author{
Ni Made Puspita Dewi ${ }^{1}$, Silvia Damayanti ${ }^{2}$, I Made Budiana ${ }^{3}$ \\ ${ }^{[123]}$ Program Studi Sastra Jepang, Fakultas Ilmu Budaya, Universitas Udayana \\ ${ }^{1}$ [puspitadewi398@yahoo.com] [2[silvia_damayanti@unud.ac.id] \\ 3[made_budiana@unud.ac.id] \\ *Corresponding Author
}

\begin{abstract}
This research entitles "Semiotic of che.r.ry and summer song by Yui Yoshioka". The purpose of this research is to know the meaning of the song Che.r.ry and summer song. The method choosen for this research is Descriptive Analysis and Informal Method. The theory used is Semiotics Theory by Riffaterre. As the result, The meaning of che.r.ry song is first love. There is symbolic figure such as sakura (cherry blossom) that symbolized as human, hoshi (star) that symbolized as a wish, and haru (spring) as a sign of time change. The second song is Summer Song that described unexplained love. Beside that, niji (raimbow) that symbolized as someone who being loved, himawari (sun flower) as a loyality, yokaze (night wind) as a situation and name no oto (voice of wave) as an imajination.
\end{abstract}

Keywords : Semiotics of Riffaterre, Love

\begin{abstract}
Abstrak
Penelitian ini berjudul "Semiotika dalam lagu che.r.ry dan summer song karya Yui Yoshioka". Tujuan penelitian ini untuk mengetahui makna dalam lagu Che.r.ry dan summer song. Metode yang digunakan dalam penelitian ini adalah metode deskriptif analisis dan metode informal. Teori yang digunakan dalam penelitian ini adalah teori semiotika Riffaterre. Berdasarkan hasil analisis, semiotika yang di dapat dalam lagu Che.r.ry ialah cinta pertama, terdapat majas simbolik yaitu sakura (bunga sakura) yang disimbolkan sebagai seseorang, hoshi (bintang) sebagai harapan, dan haru (musim semi) sebagai tanda pergantian waktu. Pada lagu yang kedua yaitu Summer song, Summer song adalah cinta yang tidak diungkapkan. Terdapat majas niji (pelangi) disimbolkan sebagai seseorang yang dicintai, himawari (bunga Matahari) sebagai kesetiaan, yokaze (angin malam) sebagai situasi dan nami no oto (suara ombak) sebagai imajinasi.
\end{abstract}

Kata Kunci : semiotika Riffatere,cinta

\section{Latar Belakang}

Lirik lagu merupakan suatu karya sastra yang disusun oleh seorang penggubah lagu yang mengungkapkan isi hati, ide, harapan bahkan kritikan kepada pendengar melalui sebuah lagu. Sebuah lagu disusun oleh seorang penggubah dengan memeperhatikan berbagai macam hal mulai dari pemilihan kata-kata yang tepat sehingga tinggi rendahnya nada dari sebuah lagu agar makna atau maksud dari seorang penyanyi bisa dimengerti oleh semua penggemar lagu tersebut. Musik $J$ pop merupakan salah satu genre musik yang sangat digemari dan populer digemari dan populer diJepang. 
Dalam penelitian ini, peneliti menggunakan skripsi yang berjudul "Makna Syair Lagu Sakura Dalam Dua Lagu J-pop Berjudul Sakura Karya Naotaro Moriyama dan Kentaro Kobuchi", Praharsacitta (2016), Sebagai bahan acuan dan refrensi. Lirik lagu $J$ pop yang akan di analisis dalam penelitian ini adalah lirik lagu yang berjudul che.r.ry dan summer song, kedua lagu tersebut dipopulerkan oleh Yui Yoshioka. Kedua lagu ini pernah menjadi lagu yang digemari oleh masyarakat Jepang, hal ini dapat dilihat dari tangga lagu oricon yang pernah didudukin oleh lagu che.r.ry dan summersong.

Diharapkan penelitian ini dapat memberikan kontribusi yang positif terhadap ilmu sastra. Sedangkan tujuan khususnya mengetahui semiotika dalam lagu che.r.ry dan summer song karya Yui Yoshioka.

\section{Pokok Permasalahan}

Berdasarkan latar belakang tersebut, masalah pokok yang hendak dibahas pada penelitian ini adalah sebagai berikut. a. Bagaimanakah makna lirik lagu che.r.ry karya Yui Yoshioka?

b. Bagaimanakah makna lirik lagu summer song karya Yui Yoshioka?

\section{Tujuan Penelitian}

Tujuan penelitian dibagi menjadi dua yaitu tujuan umum dan tujuan khusus. Secara umum penelitian ini bertujuan untuk memahami dan mempelajari bentuk karya sastra Jepang, meningkatkan apresiasi masyarakat terhadap karyasastra. Sedangkan tujuan khususnya mengetahui makna lagu che.r.ry dan summer song karya Yui Yoshioka.

\section{Metode Penelitian}

Metode yang digunakan dalam penelitian ini adalah metode kualitatif.
Metode kualitatif memberikan perhatian terhadap data ilmiah, dalam ilmu sastra sumbernya adalah karya, naskah, dan penelitiannya, dan sebagai data formal adalah kata-kata, kalimat dan wacana (Ratna, 2009:46). Metode pengumpulan data yang digunakan adalah metode studi pustaka. Metode studi pustaka dilakukan dengan cara membaca data-data yang berkaitan dengan objek penelitian, yaitu syair lagu che.r.ry dan summer song karya Yui Yoshioka kemudian mencatat hal-hal yang berhubungan dengan analisis makna syair lagu tersebut.

\section{Hasil dan Pembahasan \\ 5.1 Che.r.ry}

Lagu che.r.ry karya Yui Yoshioka ini mengambil tema tentang cinta. Lagu ini mengisahkan seorang perempuan yang sedang jatuh cinta dan disimbolkan dengan bunga sakura yang sedang bermekaran. Untuk liriknya, Yui mencoba menyesuaikan dengan nuansa musim semi dan mengambil kisah cinta anak-anak SMA. Kata Cherry menurut Yui memiliki makna cinta pertama. penelitian ini menggunakan teori semiotika yang dikemukakan oleh Riffatere yaitu : (1) ketidaklangsungan ekspresi, (2) pembacaan heuristik dan heurmeneutik dan (3) matriks, model dan varian.

\subsubsection{Penggantian Arti}

Penggantian arti adalah ketika terjadi perubahan makna dari satu tanda ke tanda yang lain, ketika adanya perbandingan satu kata menggantikan kata yang lain, hal ini terjadi pada metafora dan metonimi (Riffatere: 1978:2). Selain metafora dan metonimi, juga terdapat beberapa bahasa kiasan yang lain, seperti personifikasi, simile, simbolik, dan sebagainya. Lagu Che.r.ry karya Yui Yoshioka merupakan lagu yang meceritakan tentang seorang gadis remaja yang sedang jatuh cinta. Penyair 
menggunakan judul Che.r.ry karena selain buah ceri itu manis, ceri disini juga memiliki makna lain yaitu perasaan yang sedang berbunga-bunga. Bahasa kiasan yang terdapat dalam lirik lagu che.r.ry karya Yui Yoshioka yaitu majas simbolik diantaranya hoshi (bintang) sebagai harapan, dan haru (musim semi) sebagai tanda pergantian waktu

\section{a. Simbolik}

Majas simbolik termasuk dalam salah satu kategori majas perbandingan. Sesuai dengan namanya, majas simbolik merupakan gaya bahasa yang membandingkan suatu hal dengan simbol lain, dapat berupa lambang, tokoh, hewan, ataupun benda. Simbol yang digunakan dalam majas ini mempunyai makna tertentu yang mewakili suatu hal yang ingin disampaikan. Dengan kata lain, majas simbolik digunakan untuk menyampaikan pesan secara tersirat atau implisit. Simbol yang digunakan merupakan simbol yang sudah umum digunakan.

Dalam penelitian ini, lagu Che.r.ry berarti cinta pertama, adapun diksi atau pemilihan katanya yang berkaitan dengan cinta pertama ialah //Sakura ga saiteiru//. Berikut merupakan majas simbolik yang terdapat dalam syair lagu che.r.ry karya Yui Yoshioka :

\section{Data 2 : さくらが咲いている}

\section{この部屋から見えてる景}

\section{色を全部}

\section{Sakura ga saiteiru \\ Kono heya kara mieteru \\ Keshiki wo zenbu}

Bunga sakura bermekaran

Aku bisa melihat pemandangan itu dari kamarku

(CHE.R.RY, 2007)

Pada data (2) merupakan penggalan bait keenam yang diwakili oleh diksi yaitu sakura. Dalam data (2) penyair menceritakan tentang bunga sakura yang bermekaran. Penyair menggunakan kata さくら (Sakura) dalam lirik lagu tersebut adalah untuk melambangkan sebuah harapan baru yaitu //Sakura ga saiteiru// yang diartikan bunga Sakura yang bermekaran. Bunga sakura yang bermekaran memiliki arti kebahagian dalam mitologi masyarakat Jepang. Tetapi didalam syair lagu tersebut penyair menggantinya dalam bentuk kisah cinta yang dirasakan pertama kali. Ini dapat dilihat dari kata bunga sakura yang bermekaran. Bunga sakura disini disimbolkan sebagai seseorang dan bermekaran disimbolkan sebagai kebahagian pertama kali.

Pada data di atas terdapat kata "sakura". Secara etimologis, menurut Nelson (2005:500), kata sakura yang tertulis dalam kanji Jepang 桜 atau 櫻 yang diartikan sebagai pohon ceri yang berbunga atau suatu nama dari jenis bunga. Lirik tersebut menceritakan seluruh panorama yang terlihat adalah bunga sakura yang sedang bermekaran pada musim semi yang diartikan bahwa gadis remaja tersebut sedang merasakan hati yang senang dan diibaratkan berbunga-bunga bagaikan bunga Sakura yang bermekaran di musim semi.

Menurut Aikawa Sakura yang berbunga pada musim semi, merupakan simbol kebahagiaan dan sukacita serta harapan dalam memulai segala sesuatu yang baru bagi masyarakat Jepang. Sakura juga menjadi metafora untuk ciriciri kehidupan yang tidak kekal bagi masyarakat Jepang. 


\subsubsection{Pembacaan Heuristik dan Hermeneutik}

Pembacaan Heuristik dan Hermeneutik merupakan pembacaan berdasarkan struktur bahasa atau secara sistem semiotik tingkat pertama (Riffatere, 1978:5). Pada artikel ini pembacaan Hermeneutik akan dijabarkan sebagai berikut.

\section{Pembacaan Hermeneutik:}

Pada bait pertama itu diterangkan keadaan dimana seseorang menerima sebuah pesan berupa emoticon yang membuat hatinya berdebar. Pesan emoticon disini digambarkan sebagai sebuah pesan singkat yang diterima pertama kali dari seseorang yang membuat hatinya senang. Ini terlihat ketika pengarang menggambarkan bahwa seseorang yang digambarkan menerima pesan emoticon tersebut tidak menyukai emoticon tetapi ketika menerima sebuah pesan emoticon hatinya berdebar seakan pesan emoticon tersebut merupakan pesan cinta yang dikirimkan seseorang.

Bait kedua secara struktural berhubungan dengan bait pertama bahwa ketika menerima sebuah pesan tersebut ia merasakan yang namanya jatuh cinta. Tetapi ia seakan tidak menyadari apa yang telah ia rasakan. Pada bait ini juga diterangkan bahwa ia telah menitipkan harapannya pada langit yang bertabur bintang. Disini juga diterangkan bahwa ia membalas pesan singkat yang dikirimkan seseorang padanya. Ini dapat dilihat dari penggunaan kata "kutitipkan harapanku pada langit bertabur bintang" dan "kukirimkan pesan untukmu dengan ujung jemariku ini"

Bait ketiga menerangkan tentang bunga sakura yang bermekaran yang disimbolkan sebagai harapan baru. Ini terlihat penggalan lagu di atas yang menggunakan kalimat bunga sakura yang bermekaran, dimana orang Jepang sering menggunakan kata sakura untuk melambangkan kebahagiaan.

Bait keempat diterangkan keadaan ketika mulai merasakan jatuh cinta. Ini dapat dilihat dari kalimat awal tumbuhnya cinta hatiku serasa sesak. Selain itu juga digambarkan situasi musim yaitu musim semi dimana musim semi bunga sakura mulai bermekaran. Pada bait keempat ini terdapat ambiguitas dalam kalimat //Mune ga kyun to semaku naru// ( hatiku terasa sesak), makna dari hatiku terasa sesak merupakan sebuah rasa sakit yang disebabkan oleh rasa cinta dalam hati seseorang. Hati yang dimaksud dalam penggalan lirik lagu diatas bukan hati yang merupakan organ dalam tubuh manusia, namun melainkan perasaan.

\subsection{Summer Song}

Lagu Summer Song merupakan lagu yang mengambil tema pada musim panas yang dalam bahasa Jepang disebut dengan 夏 natsu. Sekolah di Jepang memberi libur musim panas sekitar sebulan. Salah satu aktivitas yang disukai kaum muda Jepang di musim panas adalah bermain ke pantai dan ke laut.

Dalam lagu Summer Song yang dipopulerkan oleh Yui Yoshioka ini menceritakan tentang kisah cinta seorang remaja yang malu mengungkapkan isi hatinya dan untuk latarnya sendiri penyair mengambil tema ketika musim panas. Untuk mengetahui makna yang terkandung dalam syair lagu Summer Song karya Yui Yoshioka, maka penelitian ini menggunakan teori semiotika yang dikemukakan oleh Riffatere pada bab sebelumnya yaitu : (1) ketidaklangsungan ekspresi, pembacaan heuristik dan heurmeneutik dan (3) matriks, model dan varian. 


\subsubsection{Penggantian Arti}

Penggantian arti adalah ketika terjadi perubahan makna dari satu tanda ke tanda yang lain, ketika adanya perbandingan satu kata menggantikan kata yang lain, hal ini terjadi pada metafora dan metonimi (Riffatere: 1978:2). Selain metafora dan metonimi, juga terdapat beberapa bahasa kiasan yang lain, seperti personifikasi, simile, simbolik, dan sebagainya. Bahasa kiasan yang terdapat dalam lirik lagu Summer Song karya Yui Yoshioka yaitu majas simbolik diantaranya Summer song adalah cinta yang tidak diungkapkan. Terdapat majas niji (pelangi) disimbolkan sebagai seseorang yang dicintai, himawari (bunga Matahari) sebagai kesetiaan, yokaze (angin malam) sebagai situasi dan nami no oto (suara ombak) sebagai imajinasi.

Simbolik

Berikut merupakan majas simbolik yang terdapat dalam syair lagu Summer Song karya Yui Yoshioka :

Data 4: 夏が来るから

海へ来たんだ

虹になったあの空を

忘れたくない

Natsu ga kuru kara

Umi e kitan da

Niji ni natta ano sora wo

Wasuretakunai

Karena musim panas

menyapa

Aku pun pergi ke pantai

Aku tak ingin melupakan

Langit yang berhias pelangi

kala itu

(Summer Song, 2008)

Pada data (4) terdapat majas simbolik yang diwakili diksi 虹 Niji. Pada lirik lagu di atas yang berjudul summer song penyair menceritakan seorang remaja yang telah memendam perasaan kepada seseorang namun ia tidak berani mengungkapkan perasaannya. Setelah itu ia pun menunggu lama untuk bisa mengungkapkannya. Bertepatan dengan musin panas 夏(natsu) ia memberanikan diri untuk mengungkapkan perasaannya. Niji dalam syair lagu tersebut disimbolkan sebagai seseorang yang ia cintai dapat dilihat dari syair //Niji ni natta ano sora wo wasuretakunail/ yang artinya "aku tak ingin melupakan langit yang berhias pelangi" bahwa gadis tersebut enggan untuk melupakan pria yang dia cintai walaupun cintanya tidak berbalas.

Natsu biasanya diawali dengan satu minggu musim hujan yang disebut Tsuyu, setelah itu musim panas yang cerah dan hangat akan melingkupi Jepang sampai akhir September. Salah satu yang menjadi ciri khas musim panas di Jepang adalah pohon-pohon yang hijau dan suara serangga yang ribut. Sekolah di Jepang memberi libur siswanya di musim panas sekitar sebulan penuh. Salah satu aktivitas yang disukai kaum muda Jepang di musim panas adalah bermain ke pantai. Sama seperti pada lirik lagu di atas yaitu summer song yang mengambil tema ketika musim panas.

\subsubsection{Pembacaan Heuristik dan Hermeneutik}

Berikut merupakan pembacaan Hermeneutik dalam lagu Summer Song karya Yui Yoshioka.

\section{Pembacaan Hermeneutik:}

Pada bait pertama menerangkan situasi musim pada saat itu yaitu musim panas yang terdapat pada kalimat sinar matahari membakar. Pada bait ini juga diterangkan mengenai harapan yang sangat besar terhadap seseorang. Sehingga penyair menggambarkan seseorang yang memiliki suatu harapan 
tentang perasaan yang dialami kepada seseorang yang dimaksud.

Bait kedua menerangkan tentang keadaan perempuan yang telah memikirkan seseorang yang ia cintai disaat musim panas sedang berlangsung. Walaupun ia sedang mengalami kebimbangan dalam hidupnya tetapi berusaha untuk melupakannya sejenak. Pada bait ini juga diterangkan keadaan dimana ketika bertemu perasaan yang bimbang berubah menjadi bahagia yang terdapat pada kalimat saat aku bertemu denganmu dan tertawa bersama.

Bait ketiga berbubungan dengan bait kedua bahwa perempuan tersebut masih memikirkan seseorang yang ia cintai dan berlanjut di malam hari. Pada bait ini digambarkan bahwa situasi pada saat itu adalah malam hari yang terdapat pada kalimat suara kembang dan angin malam. Disini juga pengarang menggambarkan bahwa perempuan tersebut masih merasa bimbang dengan perasaan yang dialami pada saat itu dapat dilihat pada kalimat walaupun tak mendengar kata-kata itu tapi aku mengerti.

Bait keempat melukiskan seorang remaja yang telah memendam perasaan kepada seseorang namun ia tidak berani mengungkapkan perasaannya. Setelah itu ia pun menunggu lama untuk bisa mengungkapkannya. Bertepatan dengan musin panas 夏(natsu) ia memberanikan diri untuk mengungkapkan perasaannya. Niji dalam syair lagu tersebut disimbolkan sebagai seseorang yang ia cintai dapat dilihat dari kalimat aku tak ingin melupakan langit yang berhias pelangi bahwa gadis tersebut enggan untuk melupakan pria yang dia cintai walaupun cintanya tidak berbalas

\section{Simpulan}

Lagu Che.r.ry karya Yui Yoshioka merupakan lagu yang meceritakan tentang seorang gadis remaja yang sedang jatuh cinta. Dalam lagu ini penyair menceritakan tentang seorang gadis yang baru memulai merasakan jatuh cinta. Penyair menggunakan judul Che.r.ry karena selain buah ceri itu manis, ceri disini juga memiliki makna lain yaitu perasaan yang sedang berbunga-bunga. Melalui lagu ini penyair mengungkapkan perasaan seorang gadis yang sedang jatuh cinta namun perasaan tersebut masih dipendam dan tak brani untuk mengungkapkannya.

Berdasarkan hasil analisis, semiotika yang di dapat dalam lagu Che.r.ry ialah cinta pertama, terdapat majas simbolik yaitu sakura (bunga sakura) yang disimbolkan sebagai seseorang, hoshi (bintang) sebagai harapan, dan haru (musim semi) sebagai tanda pergantian waktu.

Sedangkan Lagu Summer Song yang juga di populerkan oleh Yui Yoshioka merupakan lagu yang menceritakan tentang seorang gadis yang sedang beranjak dewasa dan mulai merasakan jatuh cinta, namun masih malu-malu untuk mengungkapkannya. Bertepatan ketika musim panas tiba ia mulai berani untuk menunjukan perasaanya tersebut. Pada lagu Summer Song musim panas yang dimaksud adalah rasa keberanian. Terdapat majas niji (pelangi) disimbolkan sebagai seseorang yang dicintai, himawari (bunga Matahari) sebagai kesetiaan, yokaze (angin malam) sebagai situasi dan nami no oto (suara ombak) sebagai imajinasi.

\section{Daftar Pustaka}

Nelson, Richard Andrew. 2005. Kamus Kanji Modern Jepang-Indonesia. Jakarta : Kesaint Blanc.

Ratna, N.K. 2009. Teori, Metode, dan Teknik Penelitian Sastra. Yogyakarta: Pustaka Pelajar. 
Riffaterre. Michael. 1978. Semiotics of Poetry. Bloomington: Indiana University Press.

Praharsacitta. 2016. Makna Syair Lagu Sakura Dalam Lagu J-Pop Berjudul Sakura Karya Naotaro Moriyama dan Kentaro Kobuchi. 